\title{
Twee gedigte
}

Adri Breed $^{1}$

\section{Skil}

Om nugter te wees

is om 'n pomelo te skil

om sy wîe te skei,

om elke garing af te rafel,

elke wig so huid-uit om te dop,

dat jy elke sel sap

alleen

kan proe.

\section{Die ontmanning van ' $n$ man en van 'n vrou}

Gala avec Cotelettes (1933) en Cenisitas (1927) van Salvador Dali

I.

skille

van 'n mensekop

velle

van 'n pienk roosknop

hangend

soos slappe lint

haar man

word voor haar kind

II.

in dié land is vir ons bekend

landskappe van pienkwit velle

dinge wat geamputeerd hang soos

piele

hiér koester ons net doodstil wrokke

in ons slape in die nag

en in die dag is als weer wel

asof ons dán iets goeds verwag 